\title{
Population size of threatened and endemic birds of the Cerrado in Estação Ecológica de Itirapina, a fragmented area in the State of São Paulo, Brazil
}

\author{
MIEKO FERREIRA KANEGAE
}

\begin{abstract}
The pressures for land use change have led to an increasing isolation of habitat remnants throughout the world. The goal of this study was to estimate the population size and density of some endemic and threatened species in a nature reserve in the Cerrado biome. One hundred and thirty four point transects were undertaken at the Estação Ecológica de Itirapina (EEI), one of the last natural grassland savannah remnants in São Paulo state, in the south-east of Brazil between September and December 2006 and densities estimated for seven species (four endemic to the Cerrado, one nearendemic and two grassland specialists). Neither species reached the minimum viable population size of 500-5000 individuals. Four species, White-banded Tanager, White-rumped Tanager, Blackthroated Saltator and Sharp-tailed Tyrant have populations ranging from 112 to 248 individuals, while the other species have a low population $(<60$ individuals). The mean densities of Sharptailed Tyrant and Cock-tailed Tyrant in the EEI grassland showed similar values to those observed in larger areas of the Cerrado, which may indicate that the EEI grassland area is well conserved. In spite of the restricted size of the EEI, small areas can maintain some endemic and threatened bird populations, thus contributing to local biodiversity and the ecological processes in the region. The capacity of fragments of Cerrado ( 2,0oo ha) to maintain populations of endemic and threatened bird species is unlikely to be effective in the long term.
\end{abstract}

\section{Introduction}

The Cerrado is a biome rich in bird species, accounting for about $50 \%$ of the total number of bird species in Brazil (856 species) (Silva 1995, Silva and Santos 2005), of which 30 species are endemic (Silva and Bates 2002) and of these, 11.8\% are threatened (Marini and Garcia 2005). The main threat to the biodiversity of the Cerrado is conversion into pastures and other agricultural uses (Klink and Machado 2005, Silva and Santos 2005). The deforestation rate is higher than Amazonia, 22,000-30,000 km²/year (Machado et al. 2004). In the State of São Paulo, the natural vegetation of the Cerrado originally covered $14 \%$ of the state (SEMA 1997). Currently, it represents only o.81\% and occurs in small isolated fragments surrounded by pastures, monocultures, exotic tree plantations and urban areas (Durigan et al. 2007).

The Estação Ecológica de Itirapina (EEI) maintains one of the last natural grassland savannah remnants in São Paulo state (Motta-Junior et al. 2008). It is on the list of priority areas for bird conservation in Brazil (Bencke et al. 2006) due to its species richness and the high risk of extinction of these species. A recent survey carried out in the EEI reported a total of 231 bird species, of which $38(16.4 \%)$ are on the list of threatened species in the State of São Paulo and/or are endemic to the Cerrado (Willis 2004, Motta-Junior et al. 2008). 
A population size estimate is a fundamental parameter for applied ecology (Newson et al. 2008). With this information it is possible to assess threatened and rare species for the IUCN Red List (IUCN 2009) and identify the most important areas for conservation (Perez-Arteaga et al. 2005). This parameter allows a comparison of population sizes in different areas, helping to understand regional variations (Thogmartin et al. 2006). It also enables one to monitor population fluctuations and identify possible causes of decline (Salafsky and Reynolds 2005), and therefore guide conservation actions (Brambilla et al. 2011).

Only two studies of Cerrado birds have considered the issue of detectability. One was conducted in the grassland areas of the Parque Nacional da Chapada dos Veadeiros and Parque Nacional de Brasília (Braz 2008) and the other took place in cerrado sensu stricto, in an Important Bird Area (IBA) of the Chapada do Catuní, Serra do Espinhaço (Silva 2008).

Few biological studies have been undertaken on endemic and threatened Cerrado birds (Marini and Garcia 2005), especially in fragmented areas. There is a need to better understand the capacity of a 'large' Cerrado fragment to maintain bird populations as well as data concerning their disappearance and rarity in such regions (Willis 2004). Consequently, this study was set up to estimate the density and population size of four endemic birds of the Cerrado: White-rumped Tanager Cypsnagra hirundinacea, Black-throated Saltator Saltatricula atricollis, Curl-crested Jay Cyanocorax cristatellus, Collared Crescentchest Melanopareia torquata, one considered 'near endemic' White-banded Tanager Neothraupis fasciata, and two obligate grassland specialist birds, Cock-tailed Tyrant Alectrurus tricolor and Sharp-tailed Tyrant Culicivora caudacuta, in a preserved Cerrado area in São Paulo State. These species were chosen because they are indicative of the wider avifauna of the cerrado due to their endemism and specialization throughout the main cerrado vegetation communities. They were easy to detect (visually and aurally), and most of them are becoming rare in this region (Willis 2004).

\section{Methods}

\section{Study area}

This study was conducted in the Cerrado of the Estação Ecológica de Itirapina (EEI), located $230 \mathrm{~km}$ from the city of São Paulo, in the districts of Itirapina and Brotas $\left(22^{\circ} 15^{\prime} \mathrm{S} ; 47^{\circ} 49^{\prime} \mathrm{W}\right)$, with an area of 2,720 ha (Figure 1 ).

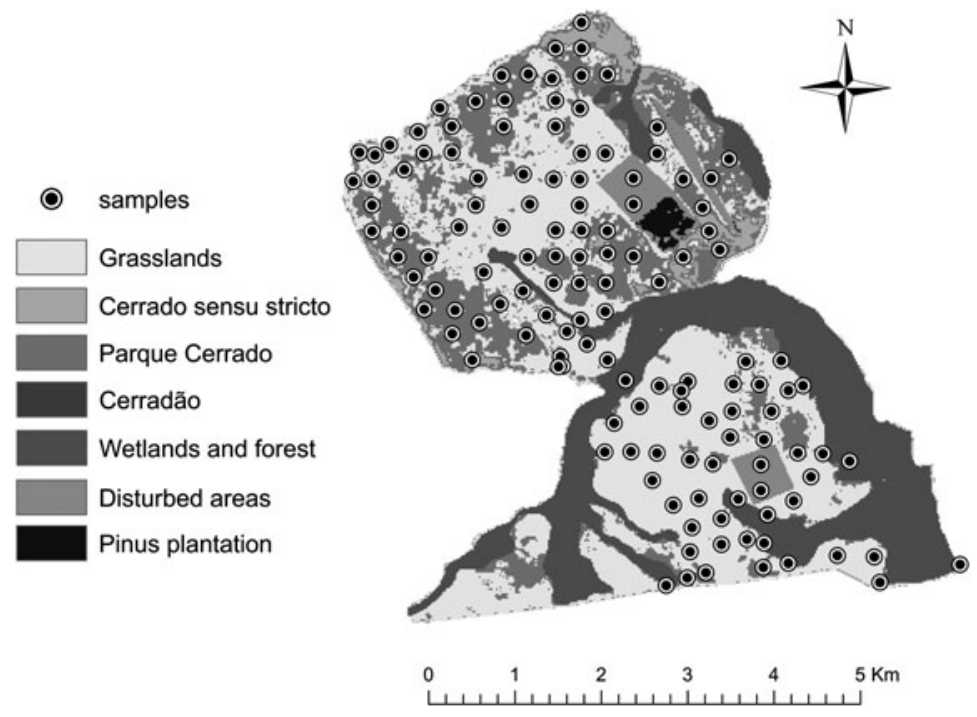

Figure 1. Total point transects during 2006 and 2007, in the Estação Ecológica de Itirapina. 
The Cerrado has a complex range of vegetation communities ranging from forests (cerradão) to grasslands (campo sujo and campo limpo) with intermediate communities such as cerrado sensu stricto and parque cerrado. The communities adopted are according to Eiten $(1972,1993)$ and Ribeiro and Walter (1998): cerradão a woodland with heights of 8-15 $\mathrm{m}$, closed scrub and cover of $50-90 \%$; cerrado sensu stricto a woodland with a continuous canopy of $20-70 \%$ and heights of $8-15 \mathrm{~m}$; parque cerrado has an intermediate density, tree cover ranges from 5 to $20 \%$ and heights of 3-6 m; grassland areas are represented by campo sujo (exclusively shrubby-herbaceous vegetation, with scattered bushes) and campo limpo (dominated by herbaceous vegetation, without woody plants) and wetland is seasonally flooded though during this study it was dry.

The altitude of the study area varied between 705 and $750 \mathrm{~m}$ (SEMA 1997). The climate is Cwa, humid subtropical, according to the Köppen (1948) classification. The mean monthly precipitation in 2006 was $109.9 \mathrm{~mm}$. The dry season, between April and September, had a monthly precipitation ranging from 7 to $79 \mathrm{~mm}$, and in the rainy season, between October and March, it was $119-228 \mathrm{~mm}$. Mean monthly temperatures in 2006 ranged between $19.5^{\circ}$ and $21.9^{\circ} \mathrm{C}$ in the dry season and $18.9^{\circ}-21.7^{\circ} \mathrm{C}$ in the wet season (DAEE Posto D4-014, Itirapina, SP).

There are many types of land use surrounding the reserve, such as cattle ranching, a condominium, and plantations of Pinus spp. and Eucalyptus spp. Among the main threats to the EEI are the expansion of exotic plants and alien trees. Other disturbance factors are invasion by hunters and non-native animals (Motta-Junior et al. 2008).

\section{Data collection}

Sampling occurred during the bird breeding season in the Cerrado, from September to December 2006, when bird vocalisations are at their most frequent (Piratelli et al. 2000, Marini and Durães 2001). Point transects, $300 \mathrm{~m}$ apart, were systematically arranged in a grid. Because these bird species had been observed in different habitats of the study area (pers. obs.), each habitat was sampled in a random order. However, each habitat was sampled in proportion to its area in the EEI (Table 1).

From September to December 2006, each point transect was sampled three times, twice in the morning (o5hoo-oghoo) and once in the afternoon (16hoo-18hoo). First, the route was determined randomly, and the direction to be followed by car. A minimum distance of $600 \mathrm{~m}$ between point transects was used to increase data independence.

The types and percentages of each habitat were obtained by analyzing the Normalized Difference Vegetation Index, based on satellite image of CBERS 2 of 17 July 2006, provided by the Instituto de Pesquisas Espaciais (INPE). The spectral signature of each vegetation community followed Mesquita Jr (1998). The scientific nomenclature follows the proposal by the Brazilian Ornithological Records Committee (CBRO 2009).

\section{Distance sampling}

Birds were detected by sound or visually with binoculars (Swift $8 \times 42$ ). Bird density and population size were estimated using point transect distance sampling (Buckland et al. 2001) and analysed using

Table 1. Types of habitat sampled and number of point transects $(n)$ and the percentages (\%) in Estação Ecológica de Itirapina (EEI), between September and December 2006.

\begin{tabular}{lrrrr}
\hline Habitats & Area (ha) & \% habitat & $n$ & $\% n$ \\
\hline Seasonal wetland & 420.12 & 17.19 & 24 & 17.91 \\
Grassland & 1162.28 & 47.57 & 68 & 50.75 \\
Parque cerrado & 571.44 & 23.39 & 30 & 22.39 \\
Cerrado sensu stricto & 121.36 & 4.97 & 6 & 4.47 \\
Cerradão & 52.88 & 2.16 & 2 & 1.49 \\
Altered area & 115.48 & 4.73 & 4 & 2.99 \\
Total & 2443.26 & 100.00 & 134 & 100.00 \\
\hline
\end{tabular}


the DISTANCE 5.1 program (Thomas et al. 2005). The distance between individual birds, or groups of birds, bird and the observer was measured with a range finder (Bushnell Yardage Pro). Distances from the bird to the point ranged from 3 to $389 \mathrm{~m}$ (Table 3 ).

Data preparation consisted of truncating the outermost $3-10 \%$ of the bird observations to minimise sampling bias. For the choice of detection function the following criteria were used: the Akaike Information Criterion (AIC) (Akaike 1973, Burnham and Anderson 2002), statistical model goodness of fit test (gof), and the shape criterion (Buckland et al. 2001) (Table 3). After all detection functions were modelled, the function with the lowest AIC value was chosen. A significant goodness of fit statistic was also a useful warning that the model might be poor and the shape criterion indicated if the model of detection function had the expected shape.

\section{Group size}

For species that occurred in monospecific and/or heterospecific flocks, such as White-rumped Tanager, Black-throated Saltator, Curl-crested Jay and Cock-tailed Tyrant, we considered a bird group as the sample unit, treated as a cluster. The size of groups that were recorded by sound only was estimated by the mean number of individuals present in all visually detected groups.

\section{Types of habitat}

Density was calculated by habitat stratification, or using covariates (Table 3 ) because of differences in vegetation structure among habitats, which can influence the detectability of species (Marques et al. 2007). The strata considered were: grassland (campo limpo and campo sujo), parque cerrado, cerradão and wetlands. Species that were detected in more than two vegetation communities were stratified. Grassland areas, campo limpo and campo sujo, were analysed together because they have a similar structure.

\section{Results}

\section{Bird density}

White-banded Tanager, Sharp-tailed Tyrant, White-rumped Tanager and Black-throated Saltator had the highest mean densities for the whole study area (Table 2). The lowest densities were recorded for Cock-tailed Tyrant, Collared Crescentchest and Curl-crested Jay.

According to the densities when stratified by habitat, Black-throated Saltator was more common in the parque cerrado than in grasslands. White-rumped Tanager and Collared Crescentchest have a similar density in grasslands and parque cerrado. The density of Collared Crescentchest per habitat was low compared to Black-throated Saltator and White-rumped Tanager (Table 2).

The coefficient of variation ranged from $14.1 \%$ to $36.9 \%$ (Table 3). Cock-tailed Tyrant and Curl-crested Jay had the largest standard errors. The encounter rate (number of animals detected by point sampling) was larger for Collared Crescentchest, Sharp-tailed Tyrant, White-banded Tanager and White-rumped Tanager in parque cerrado (Table 3). On the other hand, the probability of detection was higher for White-rumped Tanager (parque cerrado), Black-throated Saltator (campo limpo and campo sujo), Cock-tailed Tyrant and White-banded Tanager.

\section{Population size}

White-banded Tanager, White-rumped Tanager, Black-throated Saltator and Sharp-tailed Tyrant had the largest mean population sizes (Table 2). The values for the other species were less than 100 individuals. Curl-crested Jay, Cock-tailed Tyrant and Collared Crescentchest had the lowest mean population sizes. Cock-tailed Tyrant had the largest coefficient of variation $(37.7 \%)$, while for the other species it was below $25 \%$. 
Table 2. Estimated density (D - individuals $\left.\mathrm{km}^{-2}\right) \pm$ standard error $(\mathrm{SE})$ and population size $(\mathrm{N}) \pm(\mathrm{SE})$ of species of endemic and threatened birds in the Estação Ecológica de Itirapina (EEI), between September and December 2006. The confidence interval was set at 95\% (ICl - ICh: lower - higher), by habitat (cCc - parque cerrado and Cl_Cs - grasslands (campo limpo and campo sujo), CV - coefficient of variation. The calculation of the average density and population size is for the entire study area.

\begin{tabular}{|c|c|c|c|c|c|c|c|c|}
\hline Species & Habitat & $\mathrm{D} \pm \mathrm{SE}$ & $\mathrm{D}_{\mathrm{ICl}}$ & $\mathrm{D}_{\mathrm{ICh}}$ & $\mathrm{N} \pm \mathrm{SE}$ & $\mathrm{N}_{\mathrm{ICl}}$ & $\mathrm{N}_{\mathrm{ICh}}$ & $\mathrm{CV}$ \\
\hline Collared Crescentchest & $\mathrm{Cc}$ & $4.0 \pm 0.8$ & 2.6 & 6.0 & $23 \pm 4.8$ & 15 & 34 & 0.21 \\
\hline Collared Crescentchest & Cl_Cs & $3.0 \pm 0.6$ & 2.0 & $4 \cdot 3$ & $34 \pm 6.6$ & 23 & 50 & 0.19 \\
\hline Collared Crescentchest & Total area & $3 \cdot 3$ & 2.5 & $4 \cdot 4$ & 57 & 43 & 76 & 0.14 \\
\hline Sharp-tailed Tyrant & $\mathrm{Cl} \_\mathrm{Cs}$ & $9.6 \pm 2.0$ & 6.3 & 14.7 & $112 \pm 24.1$ & 73 & 171 & 0.21 \\
\hline Cock-tailed Tyrant & $\mathrm{Cl} \_\mathrm{Cs}$ & $4.6 \pm 1.7$ & 2.2 & $9 \cdot 5$ & $53 \pm 20$ & 26 & 111 & 0.38 \\
\hline Black-throated Saltator & $\mathrm{Cc}$ & $10.0 \pm 1.9$ & 6.9 & 14.6 & $57 \pm 10.8$ & 40 & 83 & 0.19 \\
\hline Black-throated Saltator & $\mathrm{Cl} \_\mathrm{Cs}$ & $6.3 \pm 1.2$ & $4 \cdot 3$ & 9.1 & $73 \pm 13.9$ & 50 & 106 & 0.19 \\
\hline Black-throated Saltator & Total area & $7 \cdot 5$ & 5.6 & 10.1 & 130 & 97 & 176 & 0.15 \\
\hline White-rumped Tanager & $\mathrm{Cc}$ & $9.2 \pm 1.3$ & 7.0 & 12.1 & $53 \pm 7.4$ & 40 & 69 & 0.14 \\
\hline White-rumped Tanager & Cl_Cs & $7.7 \pm 1.5$ & $5 \cdot 3$ & 11.2 & $89 \pm 17.1$ & 61 & 130 & 0.19 \\
\hline White-rumped Tanager & Total area & 8.2 & 6.1 & 10.9 & 142 & 106 & 198 & 0.15 \\
\hline White-banded Tanager & Cs_Cc & $14.3 \pm 3.2$ & $9 \cdot 3$ & 22.1 & $248 \pm 55 \cdot 33$ & 161 & 384 & 0.22 \\
\hline Curl-crested Jay & $\mathrm{Cc}$ & $5.5 \pm 1.2$ & $3 \cdot 7$ & 8.4 & $32 \pm 6.8$ & 21 & 48 & 0.21 \\
\hline Curl-crested Jay & $\mathrm{Cl} \_\mathrm{Cs}$ & $0.7 \pm 0.2$ & 0.4 & 1.2 & $8.0 \pm 2.4$ & 5 & 15 & 0.29 \\
\hline Curl-crested Jay & Total area & 2.3 & - & - & 40 & 25 & 63 & 0.23 \\
\hline
\end{tabular}

The lowest population size values were observed for Cock-tailed Tyrant and Curl-crested Jay followed by Collared Crescentchest.

\section{Discussion}

\section{Bird density}

The classification of the tyrant species as 'Vulnerable' was based on the extensive destruction of grassland areas in Brazil (BirdLife International 2009a,b). The minimum density of Cock-tailed Tyrant observed was 6.7 individuals $\mathrm{km}^{-2}$, which represents a value greater than the estimate used by BirdLife International (2009a) of 1 individual $\mathrm{km}^{-2}$, based on the lowest density among species in the family Tyrannidae.

The mean densities of Sharp-tailed Tyrant and Cock-tailed Tyrant observed in EEI have similar values to the Parque Nacional de Brasília (PNB, 42,389 ha) and Parque Nacional da Chapada dos Veadeiros (PNCV, 65,512 ha) (Braz 2008). The results indicate that small preserved Cerrado areas may contain similar densities, of threatened species, to large preserved areas.

In general, the density values of the birds studied, ranging from 2.3 to 14.3 individuals $\mathrm{km}^{-2}$ were similar to those observed for other Cerrado birds (Braz 2008). For Passeriformes, mean densities ranged from 3.1 to 23.2 individuals $\mathrm{km}^{-2}$ in the PNCV and from 3.4 to 14.6 individuals $\mathrm{km}^{-2}$ in the PNB (Braz 2008). The densities of birds in cerrado sensu stricto in the Chapada do Catuní (CCat, an area of 1,950 ha) ranged from 3.3 to 134.7 individuals $\mathrm{km}^{-2}$ (Silva 2008), with a maximum density greater than the other studies.

Density estimates for the endemic species considering all habitats in the EEI are lower than those obtained by Silva (2008) in the CCat. The estimate indicated by Silva was approximately twice as large for Collared Crescentchest (six individuals $\mathrm{km}^{-2}$ ), White-rumped Tanager (14.7) and Black-throated Saltator (15.4). The most common endemic species, both in the CCat as in the EEI, was White-banded Tanager. However, this bird had a density about 10 times greater in the CCat (134.7 individuals $\mathrm{km}^{-2}$ ).

Many variations in biotic and abiotic factors may affect these differences: environmental conditions and plastic responses to changes, population demographics, species interactions, anthropogenic impacts (Sagarin et al. 2006) and habitat heterogeneity (Wiens 1974). 
Table 3. Summary of the analysis of the sampling data the Distance 5.1 program. The types of habitats (Ccc - parque cerrado, $\mathrm{Cl}$ _Cs - campo limpo and campo sujo), the analysis performed (CDS - conventional distance sampling analysis, MCDS - multiple covariate distance sampling analysis) using Akaike Information Criterion (AIC), Fun: function of key detection (SN - semi-normal, HZ - hazard rate and UN - uniform) type of adjustment (cos - cosine, sp - simple polynomial), PT - percentage of truncation, $\mathrm{N}$ - number of observations by species, Eff. - sampling effort, P.D. - probability of detection, E.R. - encounter rate, E.W. Effective Width $(\mathrm{m}) \pm$ standard error (SE), coefficient of variation and GOF Chi- $P$ - $P$ value of adhesion.

\begin{tabular}{|c|c|c|c|c|c|c|c|c|c|c|c|}
\hline Species & Habitat & Analysis & AIC & Fun & P.T. & $\mathrm{N}$ & Eff. & P.D. & E.R. & E.W. \pm SE & $\begin{array}{l}\text { GOF } \\
\text { Chi- } P\end{array}$ \\
\hline $\begin{array}{l}\text { Collared } \\
\text { Crescentchest }\end{array}$ & Cc & CDS & 202.54 & $\mathrm{UN} \cos$ & $10 \%$ & 63 & 135.0 & 0.37 & 0.63 & $192.87 \pm 12.33$ & 0.80 \\
\hline $\begin{array}{l}\text { Collared } \\
\text { Crescentchest }\end{array}$ & Cl_Cs & CDS & 278.88 & UN $\cos$ & $10 \%$ & 87 & 217.0 & 0.47 & 0.53 & $207.97 \pm 13.85$ & 0.78 \\
\hline Sharp-tailed Tyrant & Cl_Cs & CDS & 459.23 & UN $\cos$ & $5 \%$ & 47 & 202.0 & 0.24 & 0.76 & $87.70 \pm 4.60$ & 0.49 \\
\hline Cock-tailed Tyrant & Cl_Cs & CDS & 199.28 & $\mathrm{HN}$ & O\% & 18 & 120.0 & 0.30 & 0.58 & $121.45 \pm 12.52$ & 0.56 \\
\hline $\begin{array}{l}\text { Black-throated } \\
\text { Saltator }\end{array}$ & $\mathrm{Cc}$ & CDS & 718.88 & $\mathrm{HN}$ & $5 \%$ & 66 & 168.0 & 0.54 & 0.32 & $139.64 \pm 9.76$ & 0.07 \\
\hline $\begin{array}{l}\text { Black-throated } \\
\text { Saltator }\end{array}$ & Cl_Cs & CDS & 781.18 & $\mathrm{HN}$ & $5 \%$ & 71 & 216.0 & 0.59 & 0.27 & $161.83 \pm 11.8$ & 0.36 \\
\hline $\begin{array}{l}\text { White-rumped } \\
\text { Tanager }\end{array}$ & Cc & CDS & 98.8 & $\mathrm{UN} \cos$ & $5 \%$ & 50 & 111.0 & 0.44 & 0.34 & $176.49 \pm 8.18$ & 0.36 \\
\hline $\begin{array}{l}\text { White-rumped } \\
\text { Tanager }\end{array}$ & Cl_Cs & CDS & 183.48 & $\mathrm{HN}$ & $5 \%$ & 88 & 153.0 & 0.68 & 0.21 & $218.47 \pm 17.27$ & 0.34 \\
\hline $\begin{array}{l}\text { White-banded } \\
\text { Tanager }\end{array}$ & Cs_cc & MCDS & 567.64 & $\mathrm{~Hz}$ & $5 \%$ & 55 & 311.0 & 0.34 & 0.56 & $84.54 \pm 5.49$ & 0.08 \\
\hline Curl-crested Jay & Cc & CDS & 740.99 & UN pol & $3 \%$ & 65 & 174.0 & 0.21 & 0.28 & $241.76 \pm 11.75$ & 0.98 \\
\hline Curl-crested Jay & Cl_Cs & CDS & 180.97 & UN & $3 \%$ & 16 & 185.0 & 0.26 & 0.74 & 327.00 & 0.37 \\
\hline
\end{tabular}

Despite the large distance between the EEI and the CCat $(>700 \mathrm{~km})$, both localities are edge areas of the Cerrado, therefore rejecting the 'abundant-centre hypothesis' (Hengeveld and Haeck 1982). This hypothesis states that species are most abundant in the centre of their range and decline in abundance toward the range edges. This hypothesis is also not supported when the density of grassland species in the EEI is compared with the reserves located in central Brazil (Braz 2008).

\section{Population size}

The Sharp-tailed Tyrant and Cock-tailed Tyrant both showed small population sizes in the studied area, which is in agreement with their rare occurrence in the south of Brazil (Parker and Willis 1997), and their declining population in the Itirapina region (Parker et al. 1996; Willis 2004). These species are threatened by grassland conversion to pasture and monoculture especially sugarcane and exotic trees (Pinus spp. and Eucalyptus spp.) (Willis 2004). The Sharp-tailed Tyrant is probably confined to the EEI area as it is highly sensitive to the altered areas (Tubelis and Cavalcanti 200o) surrounding the reserve, which are dominated by exotic grasses. Also it has a low capacity for flight (pers. obs.), and only makes short movements in the understorey. The Cock-tailed Tyrant, however, is reported to be able to make extensive movements and is considered to be both nomadic and resident. During the present study, this species was rarely detected in September and December, compared with October and November, indicating an unknown movement outside the reserve during these months.

In larger protected areas of central Brazil $(>40,000$ ha) the mean population size estimated by distance sampling can reach between 1,022 and 1,786 individuals $\mathrm{km}^{-2}$ for Sharp-tailed Tyrant, 
and 1,374 for Cock-tailed Tyrant (Braz 2008). Since the EEI grassland area is one of the only conserved areas in the region, it is important to develop actions to increase these areas and their habitat quality, in order to allow population growth.

The Collared Crescentchest had a small population in the EEI, which according to Willis (2004) seems to be decreasing. In São Paulo state its situation is critical due to habitat destruction. Less than $1 \%$ remains as Cerrado and the remaining areas occur in small and isolated fragments (Durigan et al. 2007). The species is recorded in only two isolated reserves, the EEI and the Estação Ecológica de Águas de Santa Bárbara (2,712 ha) (São Paulo 2009) which reinforces the conservation importance of these areas.

Although the Chapada do Catuní (CCat) is smaller than the EEI, a larger population of Collared Crescentchest was found. This is probably due to the dominance of cerrado sensu stricto in the CCat. In the EEI this species was found mainly in campo cerrado vegetation, and also sporadically observed in campo sujo (unpubl. data). The campo cerrado vegetation in the EEI (412 ha) has the same structure as cerrado sensu stricto (2,00o ha) in the CCat, but differing in the classification and the subjective evaluation of it (Silva, pers. comm.). The species probably has a low capacity for movement in open areas such as pastures and plantations due to its preference for understorey vegetation.

White-banded Tanager is considered 'Near Threatened' (IUCN 2009) and endangered in the State of São Paulo (São Paulo 2009). Both species have a declining population due to habitat loss and degradation for agricultural development (Willis 1994, IUCN 2009). Although it is considered Near Threatened and reported as scarce within its range (IUCN 2009) it was the most common species in both the EEI and the Chapada do Catuní (CCat) (Silva 2008). In the CCat, the species has a very large population size of 2,627 individuals. Fragments as large as the Estação Ecológica de Águas Emendadas (10,500 ha), in the centre of Brazil also support a large population $(3,438$ individuals), but this is well below its carrying capacity (Duca et al. 2009). Compared with other species studied, White-banded Tanager seems to have larger populations in fragments of Cerrado larger than 2,00o ha.

White-rumped Tanager and Black-throated Saltator are on the list of threatened species in São Paulo State (São Paulo 2009) mainly due to loss and alteration of habitat. In the EEI, these species chose areas of parque cerrado, since the presence of bushes and trees are important for their daily activity (Levy 2009). Compared to our results, the species had a very large population size in the CCat, averaging 286 individuals $\mathrm{km}^{-2}$ for White-rumped Tanager and 300 individuals $/ \mathrm{km}^{2}$ for Black-throated Saltator. These data indicate that the population size in the EEI is very low, around 140 individuals $\mathrm{km}^{-2}$.

The Curl-crested Jay is an opportunistic species that is not sensitive to human disturbance and it is expanding its range in south-eastern Brazil (Lopes 2008). This species is common in agricultural areas and can be found in semi-urban locations of large cities (Vasconcelos and Nemésio 2007) and in Pinus plantations in the EEI. In this study, it had the lowest population size, probably because it has a large home range ( $172 \mathrm{ha}$ ) and can form large groups of 10 individuals (Amaral and Macedo 2003). In the EEI the observation of pairs (47 records) was common probably because smaller areas do not support larger groups of crows during the reproductive period, which also limits the population size.

\section{Final considerations}

The EEI represents one of the last remaining Cerrado bird communities in the State of São Paulo. Despite its restricted size and isolation, the EEI harbours small populations of several endemic and threatened species, thus contributing to local biodiversity and ecological processes in the region. However, the capacity of fragments of Cerrado (c. 2,00o ha) to maintain bird populations in the long term is doubtful. The density of these specialist Cerrado species seems to be low compared with larger areas and indicates the importance of larger areas to maintain these populations. Small populations can persist in the wild for some time, but their ability to adapt to 
change is compromised and extirpation is likely (Willi et al. 2006, Spielman et al. 2004). In the last few decades, the area of Cerrado has been drastically reduced in Brazil and only about $34 \%$ of its original area remains (Machado et al. 2004). The area under conservation is $\mathrm{c} .33,000 \mathrm{~km}^{2}$ (Klink and Machado 2005), representing only about $1.65 \%$ of its original extent. In the state of São Paulo most of the remaining Cerrado is in isolated small fragments, $<400$ ha (Durigan et al. 2006). These small areas are ineffective in conserving endemic and threatened birds. Neither species reached the minimum viable population size of $500-5000$ individuals (Franklin and Frankham 1998, Lynch and Lande 1998). Establishment of future reserves should consider that in view of the low density of some Cerrado birds, areas of at least 30,000 ha are likely to be needed to maintain viable populations of endemic and threatened species. In EEI it is essential to carry out actions to monitor the size of these populations over time and evaluate ways of increasing the quality of the bird habitat; e.g. some ways to improve the microhabitat quality in the EEI are presented by Kanegae (2009). Furthermore, we suggest a study of the surrounding areas that could be added to the EEI. The maintenance of these areas could increase populations of some species with apparent short movements, such as the Collared Crescentchest and Sharp-tailed Tyrant, which are the most threatened species in the EEI.

\section{Acknowledgements}

I would like to thank José Carlos Motta-Junior for revising this paper and his contributions. I thank the CEMAVE, the Instituto Florestal do Estado de São Paulo (IF), and the Estação Ecológica de Itirapina for authorisation to study birds and for their support. I acknowledge Matheus Reis and Gisele Levy for their field assistance. I thank CAPES for the doctorate scholarship and Instituto de Biociências da Universidade de São Paulo, Idea Wild, The E. Alexander Bergstrom Memorial Research Award, Neotropical Grassland Conservancy, W. J. and Virginia W. Moorhouse Memorial, Pamela and Alexander F. Skutch, and Birders Exchange for the financial support and donation of equipment.

\section{References}

Akaike, H. (1973) Information theory as an extension of the maximum likelihood principle. Pp. $267-281$ in B. N. Petrov and F. Csaki, eds. Second international symposium on information theory. Budapest: Akademiai Kiado.

Amaral, M. F. and Macedo, R. H. F. (2003) Breeding patterns and habitat use in the endemic Curl-crested Jay of central Brazil. J. Field Ornithol. 74: 331-340.

Bencke, G. A., Mauricio, G. N., Develey, P. F. and Goerck, J. M. (2006) Áreas Importantes para a conservação das aves no Brasil. Parte I - Estados do Domínio da Mata Atlântica. Editora SAVE Brasil: São Paulo, Brazil.

BirdLife International (2009a) Alectrurus tricolor. In: IUCN 2010. IUCN Red List of Threatened Species. Version 2010.2. <www. iucnredlist.org >;. Downloaded on 14 July 2010.
BirdLife International (2009b) Culicivora caudacuta. In: IUCN 2010. IUCN Red List of Threatened Species. Version 2010.2. <www. iucnredlist.org $>$. Downloaded on 14 July 2010.

Brambilla, M., Gustin, M. and Celada, C. (2011) Defining favourable reference values for Bird populations in Italy setting longterm conservation targets for priority species. Bird Conserv. Internat. 21: 107118

Braz, V. S. (2008) Ecologia e conservação das aves campestres do Bioma Cerrado. Ph.D. dissertation. Brasília, Distrito Federal: Universidade de Brasília:.

Buckland, S. T., Anderson, D. R., Burnham, K. P., Laake, J. L., Borchers, D. L. and Thomas, L. (2001) Introduction to distance sampling: Estimating abundance of biological populations. New York: Oxford University Press. 
Burnham, K. P. and Anderson, D. R. (2002) Model selection and multimodel inference: a practical information-theoretic approach. New York: Springer.

CBRO (2009) Lista das aves do Brasil do Comitê Brasileiro de Registros Ornitológicos. http://www.cbro.org.br/CBRO/listabr.htm (último acesso em 24/10/2009).

Duca, C., Yokomizo, H., Marini, M.Â. and Possingham, H. P. (2009) Cost-efficient conservation for the white-banded tanager (Neothrapis fasciata) in the Cerrado, central Brazil. Biol. Conserv. 142: 563-574.

Durigan, G., Siqueira, M. F., Franco, G. A. D. C. and Ratter, J. A. (2006) Seleção de fragmentos prioritários para a criação de unidades de conservação no Estado de São Paulo. Rev. Inst. Flor. 18: 23-37.

Durigan, G., Siqueira, M. F. and Franco, G. A. D. C. (2007) Threats to the Cerrado remnants of the State of São Paulo, Brazil. Scientia Agrícola 64: 355-363.

Eiten, G. (1972) The Cerrado vegetation of Brazil. Bot. Rev. 38: 201-341.

Eiten, G. (1993) Vegetação do Cerrado. Pp. 17-73 in M. Novaes Pinto, org Cerrado: caracterização, ocupação e perspectivas. Brasília: Editora Universidade de Brasília.

Franklin, I. R. and Frankham, R. (1998) How large must populations be to retain evolutionary potential? Anim. Cons 1: 69-73.

Hengeveld, R. and Haeck, J. (1982) The distribution of abundance. I. Measurements. J. Biogeogr. 9: 303-316.

IUCN (2009) IUCN Red List of threatened species. <www.iucnredlist.org>;. Downloaded on 3 February 2009.

Kanegae, M. F. (2009) Tamanho populacional, seleção de habitat e área de vida de espécies de aves endêmicas e ameaçadas do Cerrado na Estação Ecológica de Itirapina, São Paulo. Ph.D. dissertation. São Paulo: Universidade de São Paulo.

Klink, C. A. and Machado, R. B. (2005) A conservação do Cerrado Brasileiro. Megadiversidade 1: 147-155.

Köppen, W. (1948) Climatologia. México: Fondo Cultura Economica.

Levy, G. (2009) Uso e seleção de habitat por Saltator atricollis (Aves Cardinalidae) $e$ Cypsnagra hirundinacea (Aves Thraupidae) no Cerrado da Estação Ecológica de
Itirapina, São Paulo. M.Sc. dissertation. São Paulo: Universidade de São Paulo.

Lopes, L. E. (2008) The range of the curlcrested-jay: lessons for evaluating bird endemism in the South American Cerrado. Divers. Distrib. 14: 561-568.

Lynch, M. and Lande, R. (1998) The critical effective size for a genetically secure population. Anim. Cons. 1: 70-72.

Machado, R. B., Ramos Neto, M. B., Pereira, P., Caldas, E., Gonçalves, D., Santos, N., Tabor, K., and Steininger, M. (2004) Estimativas de perda da área do Cerrado brasileiro. Brasília: Conservation International do Brasil. (In Portuguese).

Marini, M.Â.. and Durães, R. (2001) Annual cycles of molt and reproduction of passerines from central-south Brazil. Condor 103: $767-775$.

Marini, M.Â... and Garcia, F. I. (2005) Bird conservation in Brazil. Conserv. Biol. 19: 665-671.

Marques, T. A., Thomas, L., Fancy, S. G. and Buckland, S. T. (2007) Improving estimates of bird density using multiple covariate distance sampling. Auk 124: 1229-1243.

Mesquita Jr, H. N. (1998) Análise temporal com sensor orbital de unidades fisionômicas de cerrado na Gleba Pé-de-Gligante (Parque Estadual de Vassununga-SP). M.Sc. dissertation. São Paulo: Universidade de São Paulo.

Motta-Junior, J. C., Develey, P. F. and Granzinolli, M. A. M. (2008) Aves da Estação Ecológica de Itirapina, Estado de São Paulo, Brasil. Biota Neotr. 8(3). http://www. biotaneotropica.org.br/v8n $3 / \mathrm{pt} / \mathrm{abstract}$ ? inventory+bno0308032008

Newson, S. E., Evans, K. L., Noble, D. G., Greenwood, J. J. D. and Gaston, K. J. (2008) Use of distance sampling to improve estimates of national population size for common and widespread breeding birds in the UK. J. Appl. Ecol. 45: 1330-1338.

Parker, T. A. III, and Willis, E. O. (1997) Notes on three tiny grassland flycatchers, with comments on the disappearance of South American fire-diversified savannas. Ornithol. Monogr. 48: 549-555.

Parker, T. A. III, Stotz, D. F., and Fitzpatrick, J. W. (1996) Ecological and distributional databases. Pp. 113-436 in D. F. Stotz, J. W. Fitzpatrick, T. A. Parker, III, and D. K. 
Moskovits, eds. Neotropical birds: Ecology and conservation. Chicago: University of Chicago Press.

Perez-Arteaga, A., Jackson, S. F., Carrera, E. and Gaston, K. J. (2005) Priority sites for wildfowl conservation in Mexico. Anim. Conserv. 8: 41-50.

Piratelli, A., Siqueira, M. A. C. and Marcondes Machado, L. O. (200o) Reprodução e muda de penas em aves de subbosque na região leste de Mato Grosso do Sul. Ararajuba 8: 99-107.

Ribeiro, J. F. and Walter, B. M. T. (1998) Fitofisionomias do bioma Cerrado. Pp. 89166 in S. M. Sano and S. P. Almeida, eds. Cerrado: Ambiente e flora. Planaltina, Distrito Federal: Embrapa-CPAC.

Sagarin, R. D., Gaines, S. D. and Gaylord, B. (2006) Moving beyond assumptions to understand abundance distribution across the ranges of species. Trends Ecol. Evol. 21: 524530.

Salafsky, S. R. and Reynolds, R. T. (2005) Patterns of temporal variation in Goshawk reproduction and prey resources. J. Raptor Res. 39: 237-246.

São Paulo (2009) Fauna ameaçada de extinção no Estado de São Paulo: Vertebrados. Coordenação geral: P. M. Bressan, M. C. M. Kierulf, A. M. Sugieda. São Paulo: Fundação Parque Zoológico de São Paulo, Secretaria do Meio Ambiente.

SEMA. (1997) Cerrado: Bases para a conservação e uso sustentável das áreas de cerrado do Estado de São Paulo. São Paulo: Secretaria do Meio Ambiente.

Silva, J. M. C. (1995) Birds of the cerrado region, South America. Steenstrupia 21: 69-92.

Silva, J. F. (2008). Densidade e tamanho populacional de aves endêmicas e ameaçadas dentro da IBA (Important Bird Area) MGo6. M.Sc. dissertation. Brasília, Distrito Federal: Universidade de Brasília.

Silva, J. M. C. and Bates, J. M. (2002) Biogeographic patterns and conservation in the South American Cerrado: A tropical savanna Hotspot. BioScience 52: 225-233.
Silva, J. M. C. and Santos, M. P. D. (2005) A importância relativa dos processos biogeográficos na formação da avifauna do Cerrado e de outros biomas brasileiros. Pp. 219-233 in A. Scariot, J. C. Sousa-Silva and J. M. Felfili, orgs. Cerrado: ecologia, biodiversidade e conservação. Brasília: Distrito Federal MMA.

Spielman, D., Brook, B.W. and Frankham, R. (2004) Most species are not driven to extinction before genetic factors impact them. PNAS. 101: 15261-15264.

Thogmartin, W. E., Knutson, M. G. and Sauer, J. R. (2006) Predicting regional abundance of rare grassland birds with a hierarchical spatial count model. Condor 108: 25-46.

Thomas, L., Laake, J. L., Strindberg, S., Marques, F. F. C., Buckland, S. T., Borchers, D. L. Anderson, D. R., Burnham, K. P., Hedley, S. L., Pollard, J. H., Bishop, J. R. B. and Marques, T. A. (2005) Distance 5.0. Beta 5. St Andrews, UK: Research Unit for Wildlife Population Assessment, University of St. Andrews. http://www.ruwpa.st-and. ac.uk/distance/

Tubelis, D. P. and Cavalcanti, R. B. (2000) A comparison of bird communities in natural and disturbed non-wetland open habitats in the Cerrado's central region, Brazil. Bird Conserv. Internat. 10: 331-350.

Vasconcelos, M. F. and Nemésio, A. (2007) Registro da gralha-do-campo, Cyanocorax cristatellus (Temminck, 1823) em ambiente urbano de Belo Horizonte, Minas Gerais. Atual. Ornit. 138: 8-9.

Wiens, J. A. (1974) Habitat heterogeneity and avian community structure in North American grasslands. Am. Midl. Nat. 91: 195213.

Willi, Y., Buskirk, J. V. and Hoffmann, A. A. (2006) Limits to the adaptative potential of small populations. Ann. Review Ecol. Evol. Syst. 37: $433-458$.

Willis, E. O. 2004. Birds of a habitat spectrum in the Itirapina savannah, São Paulo, Brazil. (1982-2003). Braz. J. Biol. 64: 901-910. 
MIEKO FERREIRA KANEGAE

Laboratório de Ecologia de Aves, Departamento de Ecologia, Instituto de Biociências da Universidade de São Paulo, 05508-9oo São Paulo, SP, Brazil. Current address: Laboratório de Vertebrados, Departamento de Ecologia, Universidade Federal do Rio de Janeiro, 21941-590, Rio de Janeiro, RJ, Brazil. E-mail: mieko.kanegae@gmail.com

Received 6 March 2010; revision accepted 31 January 2011;

Published online 11 April 2011 